\title{
Bioaccumulation of Trace Elements in the Organisms of Benthic Communities in the Reducing Environments of the Sea of Okhotsk
}

\author{
Sergey V. Galkin ${ }^{1} \&$ Liudmila L. Demina ${ }^{1}$ \\ ${ }^{1}$ Shirshov Institute of Oceanology, Russian Academy of Sciences, Moscow, Russia \\ Correspondence: Sergey V. Galkin, Shirshov Institute of Oceanology, Russian Academy of Sciences, Moscow, \\ 117997 Russia. E-mail: galkin@ocean.ru
}

Received: May 26, 2018

Accepted: June 12, 2018

Online Published: September 29, 2018

doi:10.5539/enrr.v8n3p182

URL: https://doi.org/10.5539/enrr.v8n3p182

\begin{abstract}
A comparative study of the bioaccumulation of trace elements in benthic organisms inhabiting the area of methane seeps in the Deryugin Basin and nearby the Paramushir Island (Sea of Okhotsk) has been performed. The data pertain to both essential elements $(\mathrm{Fe}, \mathrm{Mn}, \mathrm{Ni}, \mathrm{Co}, \mathrm{Cr}$, and $\mathrm{Cu}$ ), which are necessary in certain concentrations for the metabolism of organisms, and nonessential heavy metals $(\mathrm{Cd}, \mathrm{Pb}$, and $\mathrm{Hg})$, as well as As, a toxic metalloid. Dominating representatives of the bottom fauna from the Deryugin Basin (sea anemones, clams) were characterized by high bioaccumulation coefficients of most of the elements $\left(\geq \mathrm{n} 10^{3}\right)$, regardless of their biochemical properties. The use of the coefficient $K$, which characterizes the accumulation of trace elements in the soft tissues of bivalves relative to their shells, allowed us to detect differences in the bioaccumulation character. Symbiotrophic bivalves of the family Vesicomyidae from the Deryugin Basin were characterized by the accumulation of all of the trace elements mostly in soft tissues (gills, primarily) compared to the carbonate shells (coefficient $K>1$ ). We suppose that different effect of abiotic (biological availability of elements and water turbidity) and biotic (throphic strategy) factors of the habitats may probably be a reason of such phenomenon.
\end{abstract}

Keywords: trace elements, heavy metals, bioaccumulation, benthic organisms, reducing biotopes, Deryugin Basin, Paramushir Island, Sea of Okhotsk

\section{Introduction}

Oceanic benthic communities perform various geochemical functions involving transformations of chemical elements. One of the most important function is bioaccumulation, which is associated with transformations of the trace element speciation, including toxic heavy metals (Demina \& Galkin, 2008, 2016; Goldberg, 1975; Kadar, Costa, Martins, Santos, \& Powell, 2005). The recently launched development of Okhotsk Sea mineral resources (gas and oil mining and transportation) increases the probability of anthropogenic contamination of benthic Arctic marine ecosystems (Operation Report, 2011). This calls for studying the bioaccumulation of heavy metals and As (metalloid) and provides a basis for ecological monitoring.

A new phase in studying the biogeochemistry of benthic biocenoses started in 1977 when high-temperature hydrothermal vent benthic communities were discovered at the Galapagos spreading center in the Pacific Ocean. Amazingly, extremely great biomass of macrobenthos was discovered in areas of diffuse hydrothermal seeps (Corliss \& Ballard, 1977). High-temperature acidic fluids ( $\mathrm{pH} 2-4$ ) in fast spreading ridges are up to $10^{6}$ times enriched in heavy metals relatively to the background seawater (German \& Von Damm, 2004). In the 1970s1980s, the flux of the trace elements to the water column from hydrothermal sources was thought to be a negligible because of the rapid oxidation of $\mathrm{Fe}^{2+}$ and iron deposition in the form of sulfide minerals and hydroxides in the close vicinity of fluid discharge sites (Edmond et al., 1982). Systematic studies (with particularly accurate sampling) under the GEOTRACES International Program (www.geotraces.org), which was focused at studying the biogeochemistry of trace elements and their isotopes in the ocean (Conway \& John, 2014; German et al., 2015), made it obvious that hydrothermal fluxes globally affect the cycles of trace elements in the ocean. High iron concentrations were discovered at a distance of more than $3000 \mathrm{~km}$ from hydrothermal vents at the Central Indian Ridge and the East Pacific Rise. This element is stabilized via the synthesis of organic complexes and colloids in diluted hydrothermal solutions, and its precipitation is prevented (Bennet et al., 2011; Nishioka, Obata, \& Tsumune, 2013). 
Another type of reduced biotopes is cold methane seeps (Paull, Jull, Toolin, \& Linick, 1985), which are interesting and unique from the viewpoint of ecology of the benthic fauna, the last functions by means of bacterial chemosynthesis. Bioaccumulation remains a poorly understood aspect of these processes.

In the reduced biotopes of both types, the organisms function under extremal conditions, in the water enriched in reduced compounds $\left(\mathrm{H}_{2} \mathrm{~S}, \mathrm{H}_{2}, \mathrm{CH}_{4}, \mathrm{Fe}^{2+}, \mathrm{Mn}^{2+}\right.$, and hydrocarbons), but at a local deficit in oxygen (hypoxia) or even its complete absence (anoxia). The macrozoobenthic communities are trophically dependent on the autochthonous organic matter, which is produced by chemoautotrophic sulfide-oxidizing, methanotrophic, and methane-oxidizing bacteria in the processes of chemosynthesis: the bacteria oxidize $\mathrm{CH}_{4}$ and $\mathrm{H}_{2} \mathrm{~S}$ to $\mathrm{CO}_{2}$ and $\mathrm{SO}_{4}^{2}$, and the excess cell energy released thereby makes it possible to transform $\mathrm{CO}_{2}$ into $\mathrm{C}_{\text {org }}$. However, while $\mathrm{H}_{2} \mathrm{~S}$ in the deep-sea hydrothermal processes is produced abiotically, as a result of interaction between magmatic rocks and hot acidic fluids, the source of $\mathrm{H}_{2} \mathrm{~S}$ in cold methane seeps is a microbial sulfate reduction. A very important feature of deep-sea biotopes at hydrothermal vent fields and methane seeps is a presence of bacterial mats with high biomasses of chemosynthesizing bacteria. Trace elements, first and foremost, $\mathrm{Fe}, \mathrm{Zn}, \mathrm{Co}$, and $\mathrm{Cr}$, are necessary for these microbial communities as metalloenzymes to catalyze biochemical reactions (Glass et al., 2014). The exometabolites of the chemosynthesizing bacteria serve as a source of dissolved organic matter in the deep ocean where no photosynthesis may occur. Similar to the oxidized biotopes, trace elements involved in complexation with organic molecules acquire new biogeochemical characteristics, which influence their distribution, mobility, and bioavailability in the water of the biotopes. At the same time, complexation of trace elements with organic ligands is one of the mechanisms of detoxication of the elements via decreasing their biological availability.

Hydrothermal vent biological communities have a different habitat comparing to the seep communities: they live under unstable major environmental parameters such as oscillating high temperatures and concentrations of reduced compounds, low $\mathrm{pH}$, and under a risk of volcanic eruptions. In contrast to them, cold seeps are more stable, and hence, many seep organisms are typically much larger, and their lifetimes are longer. Regard must be paid to one of the most obvious consequence of chemosynthetic activity at the anaerobic oxidation of methane is authigenic barite and carbonate minerals, which provide substrate for the benthic fauna (Greinert, Bollwerk, Derkachev, Bohrmann, \& Suess, 2002).

The major factors affecting the accumulation of trace elements in hydrothermal vent organisms have been defined over a past few years (Demina \& Galkin, 2008; Demina, Holm, Galkin, \& Lein, 2013; Kadar et al., 2005; Kádár, Costa, \& Santos, 2006; Kádár, Costa, \& Segonzac, 2007; Koschinski, 2016). However, practically no materials have been published so far on the bioaccumulation of trace elements by the dominant communities of cold methane seeps.

Our research was focused on features of the bioaccumulation of trace elements in taxa inhabiting the area of cold methane seeps in the Deryugin Basin and the area of Paramushir gas-hydrate seepage in the Sea of Okhotsk. Comparison of these data with our earlier published data on the Rainbow high-temperature hydrothermal vent field at Mid-Atlantic Ridge (MAR) allowed us to gain an insight into the differences and similarities in the bioaccumulation of trace elements in reducing oceanic biotopes.

\section{Materials and Methods}

Samples for this study were collected during $61^{\text {th }}$ cruise of the R/V Akademik M.A. Lavrentyev in the Sea of Okhotsk in May 2013. The environment and the distribution of macro and mega benthos in the area of methane seeps in Deryugin Basin and on the western slope of Paramushir Island have been explored using remotely operated vehicle (ROV) Comanche 18. The observations were accompanied by photographic and video recording. Bottom organisms were sampled using mechanical arm of ROV and brought to the shipboard in the specialized containers. The samples were then washed on a set of stainless steel sieves (with 5.0 to $1.0 \mathrm{~mm}$ mesh) and additionally washed by means of successive maceration using a hand sieve (with 0.5 -mm mesh). After this, the samples were rinsed with deionized water, certain of their organs and tissues were preparated, and the intestines were removed. After this, the samples were washed by deionized water and dried in Petri dishes in a chamber dryer at $55^{\circ} \mathrm{C}$. The size and weight of each individual organism were measured at a stationary laboratory. The mineralization of pulverized samples $(500 \mathrm{mg})$ was performed using the mixture of $1 \mathrm{~mL} \mathrm{HNO}_{3}$ (super pure MERCK) and $0.5 \mathrm{~mL} \mathrm{H}_{2} \mathrm{O}_{2}(30 \%)$ in the Teflon vessels of the MWS-2 (Berghof, Germany) microwave oven at a temperature of $120^{\circ} \mathrm{C}$. Upon cooling, $18.5 \mathrm{~mL}$ of deionized water was added to the solutions in a HDPE (Wheaton, United States) plastic flasks. Concentrations of trace elements were analyzed by inductively coupled plasma mass spectroscopy (ICP-MS) on Agilent 7500a (United States) mass spectrometer. The quality of analyses for trace elements was controlled by replicate analyses of internationally certified 
standards (SRM NIST 976 mussel tissues) from the National Institute of Standards and Technology. The differences between the measured and certified values of the standard were no greater than $\pm 25 \%$.

\section{Results and Discussion}

During the ROV observations and sampling, the landscape ecological environment and composition and structure of benthic communities have been studied.

In the Deryugin Basin, methane seeps were observed in the area named Clam Hill (54 $01^{\prime} \mathrm{N} 146^{\circ} 43^{\prime} \mathrm{E}$, depth $1407-1440 \mathrm{~m})$. Yellowish gray sediment is moderately bioturbated. Numerically dominated sessile animals are small fan-like scleractinian corals Stylaster sp. Most of them (80\% of colonies) are oriented in the same way, indicating the presence of a fairly constant northwest current (about $315^{\circ}$ ). Among the motile animals, in the studied area, the most numerous are benthic relatively small red shrimps. Large gastropods and crabs Chionoecetes angulatus are common. Sediment samples taken here indicate that it is inhabited by a fairly abundant infauna. Aside from the live pogonophora and their tubes, here are the ampharetid polychaetes, nematodes, crustaceans Tanaidacea. Visually observed "seeps" represent the spots lighter than the surrounding sediment, possibly due to the presence of bacterial mats. Such seeps are often marked by settlements of bivalve mollusks, Akebiconcha soyoae ochotensis Scarlato (Figure 1). These large clams with an average shell length of about $10 \mathrm{~cm}$ reach a weight of 183 grams (average 112 grams). They have bright red fleshy gills, which is typical for symbiotrophic mollusks. In the investigated area, these bivalves settle together, in the clusters the size of the settlements varies from 2-3 to the first dozens of living specimens. On the surface and inside of the sediment, jelly-like whitish bacterial mats are visible. When lifting some samples on the deck, the sediment produced a distinct smell of hydrogen sulfide. In the community, large sea anemones, colonial ascidians, polychaetes of Polynoidae family, glass sponges, galatheid crabs, shrimps, starfishes, and brittle stars are common.

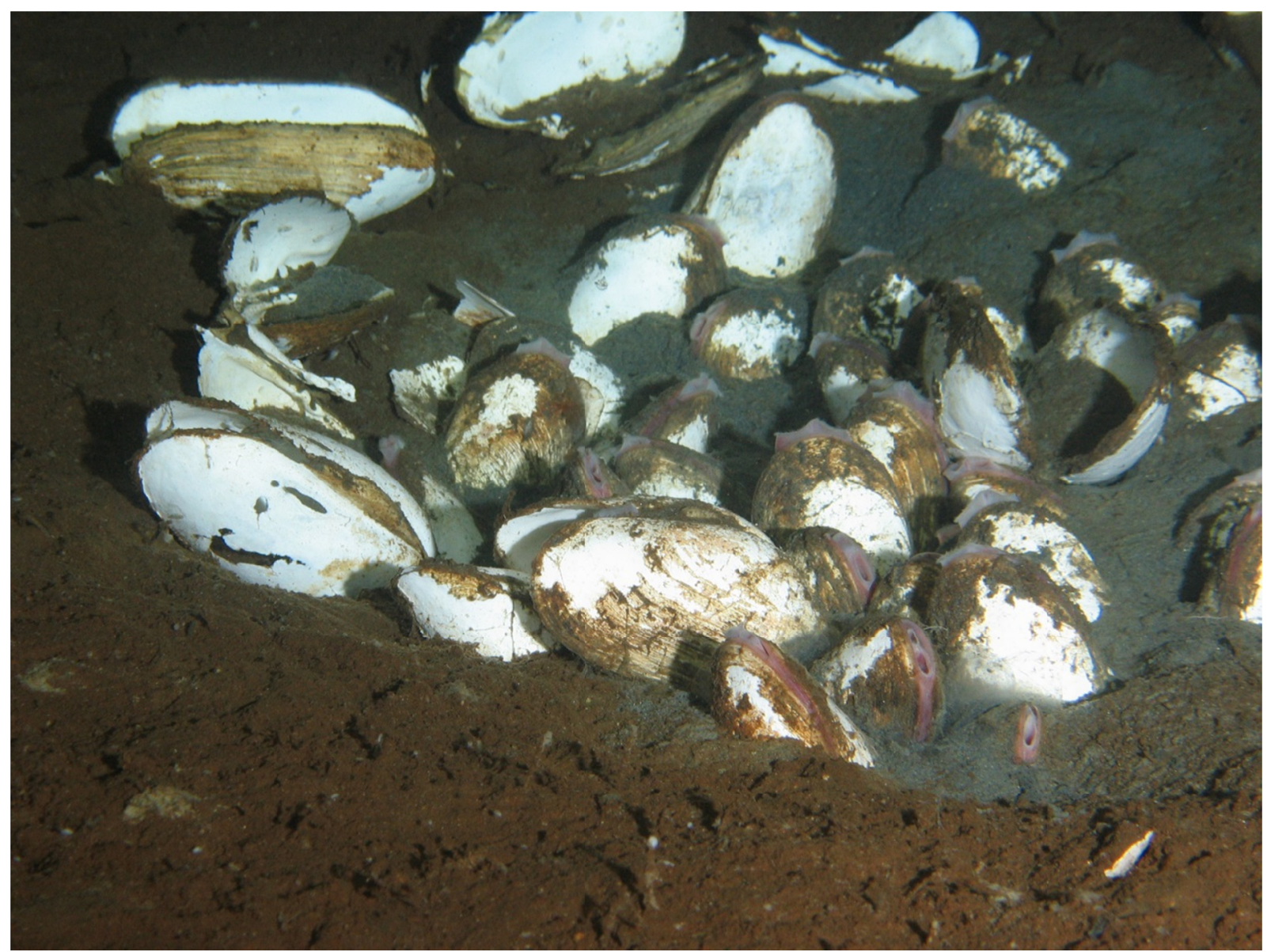

Figure 1. Sea of Okhotsk, Deryugin Basin, depth 1427 m. Assemblage of symbiotrophic mollusks Akebiconcha soyoae ochotensis (fam. Vesicomyidae) 
The area of Paramushir gas-hydrate seepage firstly discovered in $1980^{\text {th }}$ is located on the western slope of Paramushir Island $\left(50^{\circ 0} 30^{\prime} \mathrm{N}, 155^{\circ} 18^{\prime} \mathrm{E}\right)$ at the depth of 750-800 m (Kuznetsov, Rass, \& Galkin, 1989; Galkin, 1993). The active field is represented by sediments covering area approximately $50 \mathrm{~m}$ across, where diffuse outflows of free methane could be visually observed. In the sediment, relatively high concentrations of iron sulfides (up to 1.4\%) have been recorded. Background community is dominated by echinoids Brisaster latifrons, polychaetes Artacama proboscidea and Ammotrypane aulogaster. Inside the active zone of seepage, dominant animals are bivalves Conchocele bisecta (fam. Thyasiridae) (Figure 2). These mollusks are unusually large: up to $15-18 \mathrm{~cm}$ in length, weight of 120-180 g. The abundance of mollusks reached 15-20 ind. per $\mathrm{m}^{2}$ (biomass up to 3 $\mathrm{kg}$ per $\mathrm{m}^{2}$ ). Anatomical and morphometric analyses of the collected mollusks showed that mollusks have fleshy massive bright crimson gills that resemble the gills of large vesicomyids. At the same time, labial are strongly reduced. Presumably these mollusks combine nutrition by filtration with the using of the products of life activity of chemosynthetic symbiotic bacteria (Kuznetsov et al., 1989b). The second remarkable species is a polychaete Pavelius ushakovi (fam. Ampharetidae), endemic genus and species (Kuznetsov \& Levenstein, 1988). Polychaetes form on sediments dense clusters ("spots") up to several square meters; their number in these clusters is estimated to be 5,000-6,000 ind. per $\mathrm{m}^{2}$ (Figure 2).

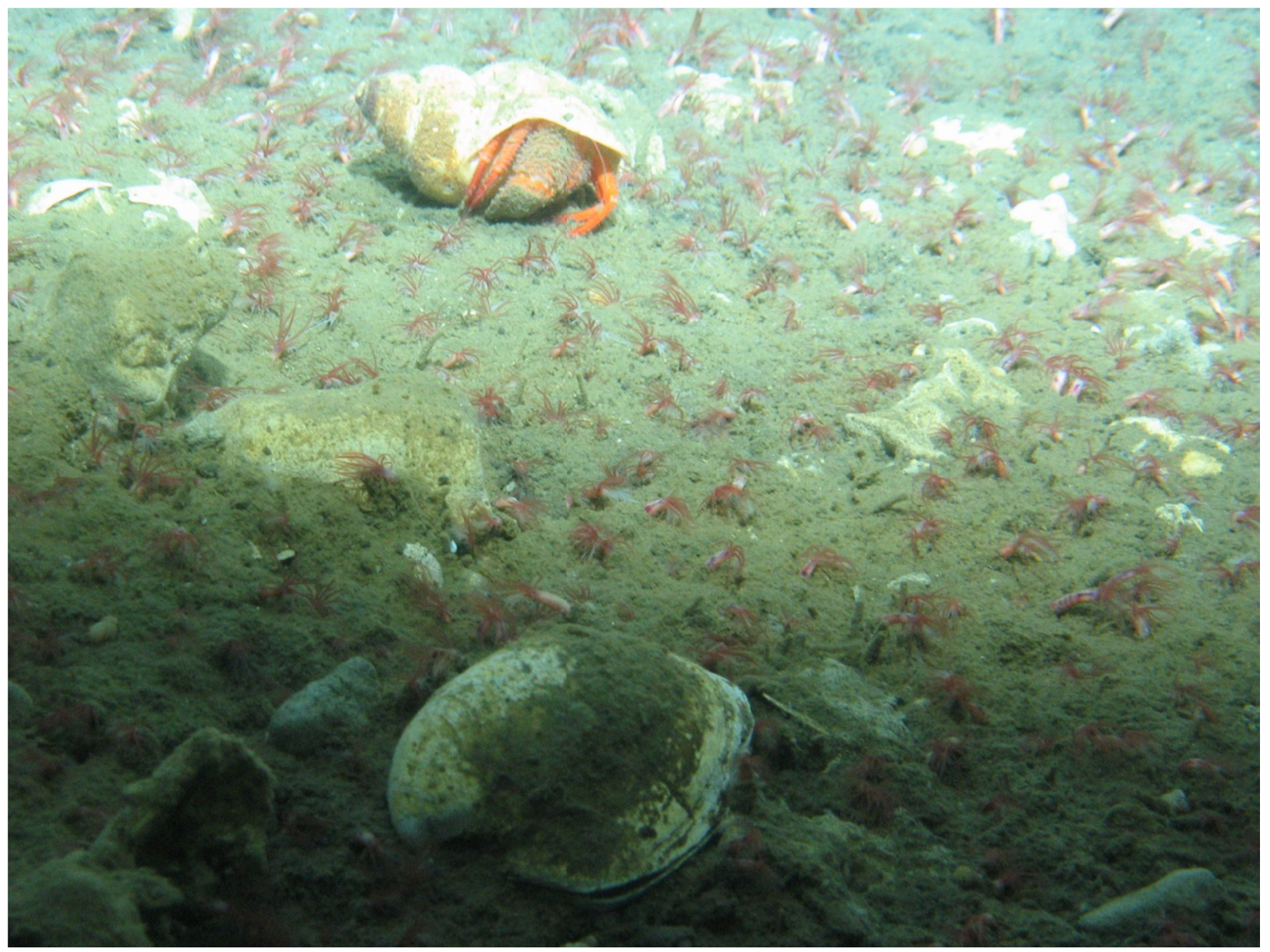

Figure 2. Sea of Okhotsk, Paramushir gas-hydrate seepage, depth 760m. Hermit crab, Conchocele bisecta shell and numerous polychaetes Pavelius ushakovi

A well-developed pharyngeal-intestinal system of these worms indicates that their feeding mode is a collecting of food particles from surface of the bottom. In the spots of accumulation of polychaetes on the sediment surface, the accumulation of filamentous bacteria were recorded. It is likely that this food source is used by polychaetes just as it occurs in hydrothermal polychaetes of Alvinellidae family, related to Ampharetidae family. Pavelius ushakovi individuals searching surrounding surface of the bottom were observed during ROV dives. Besides of these animals, within the active zone numerous crabs Chionoecetes opilio, Paralithodes brevipes, sea 
stars Myxoderma derjugini, holoturians Pannychia moselei, small gastropods Provannidae, various shrimps, hermit crabs, bottom fishes Lycogramma sp., Lycodes soldatovi, Icelus spiniger, Careproctus curilanus and some others were recorded.

The bioaccumulation of trace elements is a process controlled by many factors, including abiotic (environmental) and biotic (trophic level, feeding type, stage of ontogenesis, and taxonomic position) ones. It is known that the bioaccumulation of trace elements in soft tissues of organisms results from metabolism, whereas this processes in the shells of bivalve mollusks depends on both metabolism (biomineralization) and adsorption of trace elements on the surface of the carbonate shells. Because of this, the most important abiotic factors for the bioaccumulation of trace elements in the shells (as an outer organ of the mollusks) are the concentrations of the trace elements and their speciation in the biotope water, turbidity of the water, and the character of the substrate.

The highest average concentrations of the trace elements are typical of the waters of the biotopes at the Rainbow hydrothermal vent field (Table 1).

Table 1. Average concentrations $(\mu \mathrm{g} / \mathrm{l})$ of trace elements in the water of biotopes at the methane seeps in the Sea of Okhotsk, and the high-temperature Rainbow hydrothermal vent field, MAR

\begin{tabular}{ccc}
\hline & $\begin{array}{c}\text { Methane seep, } \\
\text { Sea of Okhotsk }\end{array}$ & $\begin{array}{c}\text { Rainbow hydrothermal vent field, Mid-Atlantic } \\
\text { Ridge }\end{array}$ \\
\cline { 2 - 3 } & $\begin{array}{c}\text { water of the biotope } \\
\text { (dissolved+particulate })^{1}\end{array}$ & $\begin{array}{c}\text { (ater of the biotope } \\
(\text { dissolved+particulate })^{2}\end{array}$ \\
\hline $\mathrm{Cr}$ & 1 & 1.6 \\
$\mathrm{Mn}$ & 3 & 190 \\
$\mathrm{Fe}$ & 25 & 2600 \\
$\mathrm{Co}$ & 10 & 0.8 \\
$\mathrm{Ni}$ & n.a. & 6.7 \\
$\mathrm{Cu}$ & 10 & 9 \\
$\mathrm{As}$ & n.a. & 76 \\
$\mathrm{Cd}$ & 0.5 & 0.7 \\
$\mathrm{~Pb}$ & n.a. & 1.2 \\
$\mathrm{Hg}$ & n.a. & 0.5 \\
\hline
\end{tabular}

${ }^{1}$ (Demina, Atnashev, 1989); ${ }^{2}$ (Demina, Galkin, 2008); nd means no data.

Among the trace elements, the highest concentrations were detected for Fe and Mn, which were the dominant metals of the high-temperature vent fluids (German \& Von Damm, 2004). In the area of submarine discharge of methane, gas hydrate accumulations on the slopes of the Paramushir Island in the Sea of Okhotsk, Fe and Mn concentrations were even lower, whereas the $\mathrm{Cu}, \mathrm{Cd}, \mathrm{Cr}$, and $\mathrm{Co}$ were close to those in the water of the hydrothermal vent biotope, with dissolved forms being dominant for $\mathrm{Fe}, \mathrm{Cu}, \mathrm{Cd}, \mathrm{Cr}, \mathrm{Co}$, and $\mathrm{Ni}$, while $\mathrm{Mn}$ was the only trace element contained mostly in the suspended particulate matter (Demina \& Atnashev, 1989).

Water turbidity affects the distribution of trace elements and the metabolism of the filter-feeding organisms. It is well known that water filtration by a mollusk colony inhabiting a seabed area of $1 \mathrm{~m}^{2}$ reaches up to 1,000 ton/day, but it drastically decreased with increase in water turbidity, and terminates completely if the water turbidity exceeds $471 \mathrm{mg} / \mathrm{L}$ (Kudinova-Pasternak, 1951). Thus, from our data, the biotope water of methane seep in the Sea of Okhotsk contains most trace elements in biologically available forms, and the benthic fauna thereby functions in more clear water as compared to that at the Rainbow hydrothermal field.

In the Deryugin Basin, methane seep are marked by bleached bacterial mat patches. Methane, a coherent product of the decomposition of low-molecular organic matter, serves as an energy source for methanotrophic bacteria, which are numerous and are characterized by highly intense biogeochemical bacterial oxidation of methane (one to two orders of magnitude higher than the background values) (Gal'chenko, 1989). Methane content in the bottom waters usually varies within the range of $1.7-3.0 \mu \mathrm{L} / \mathrm{L}$ and reaches an absolute anomaly of $5.72 \mu \mathrm{L} / \mathrm{L}$ (i.e., dozens to hundreds of times higher than in the surface waters) at the plume source. In the bottom sediment cores, particularly at the layers lower than $300 \mathrm{~cm}$, methane concentrations were still one to two orders of magnitude higher (Operation Report of Sakhalin Slope Gas Hydrate Project, 2011). According to CTD data, this reduced biotope was characterized by the physicochemical parameters: the bottom water temperature was $2.34^{\circ} \mathrm{C}$, salinity, 34.41-34.44\%o, and $\mathrm{pH} 7.60-7.62$. Methane seeps stimulate the development of symbiotrophic 
organisms, such as the bivalve Vesicomyidae Akebiconcha soyoae ochotensis. This large mollusk has an average shell length of $10 \mathrm{~cm}$ and reaches a mass of $183 \mathrm{~g}$ (at an average of $112 \mathrm{~g}$ ). Another dominant group that we studied in this area was Actiniaria, which was a predator-suspension-feeder according to its feeding type.

The average concentration of the heavy trace elements in bottom organisms inhabiting areas of cold methane seeps in the Deryugin Basin are listed in Table 2.

Table 2. Average content ( $\mu \mathrm{g} / \mathrm{g}$ dry wt. \pm standard deviation) of heavy metals and metalloid As in bootom fauna of the Deryugin Basin, Sea of Okhotsk

\begin{tabular}{|c|c|c|c|c|c|c|c|c|c|}
\hline Station, taxon, its organ & & & & & & & & & \\
\hline ( $\mathrm{n}$ - number of samples examined) & $\mathrm{Cr}$ & Mn & $\mathrm{Fe}$ & Co & $\mathbf{N i}$ & $\mathrm{Cu}$ & As & Mo & $\mathbf{P b}$ \\
\hline LV 61-4-1 Actiniaria, fragment of foot (from background area), $\mathrm{n}=3$ & $7.13 \pm 1.14$ & $26.3 \pm 5.1$ & $1120 \pm 29$ & $0.72 \pm 0.21$ & $290 \pm 73$ & $15.14 \pm 2.9$ & $71 \pm 31$ & $0.99 \pm 0.16$ & $2.23 \pm 0.18$ \\
\hline LV 61-5-1 Actiniaria, fragment of foot (from seep area), $\mathrm{n}=4$ & $3.88 \pm 0.82$ & $45 \pm 14$ & $1010 \pm 85$ & $0.31 \pm 0.09$ & $1.1 \pm 0.07$ & $10.64 \pm 2.35$ & $491 \pm 62$ & $0.51 \pm 0.12$ & $1.33 \pm 0.24$ \\
\hline LV 61-5-1 Bivalvia, Akebiconcha soyoae ochotensis, soft tissues, $\mathrm{n}=5$ & $35.8 \pm 10.1$ & $9.3 \pm 1.7$ & $222 \pm 18$ & $0.32 \pm 0.06$ & $1.42 \pm 0.03$ & $141 \pm 32$ & $12.3 \pm 3.8$ & $9.92 \pm 1.7$ & $0.15 \pm 0.02$ \\
\hline LV 61-5-1 Bivalvia, Akebiconcha soyoae ochotensis, gills, $\mathrm{n}=5$ & $82 \pm 16$ & $5.6 \pm 1.1$ & $398 \pm 53$ & $1.82 \pm 0.2$ & $5.72 \pm 1.7$ & $76.1 \pm 5.9$ & $7.88 \pm 1.8$ & $42.1 \pm 11$ & $0.32 \pm 0.04$ \\
\hline LV 61-5-1 Bivalvia, Akebiconcha soyoae ochotensis, shell, $\mathrm{n}=5$ & $0.22 \pm 0.21$ & $1.8 \pm 0.3$ & $41 \pm 7$ & $0.04 \pm 0.01$ & $0.18 \pm 0.04$ & $0.71 \pm 0.2$ & $0.12 \pm 0.03$ & $0.37 \pm 0.07$ & $0.008 \pm 0.002$ \\
\hline LV 61-5-1 Bivalvia, Akebiconcha soyoae ochotensis, soft tissues, $n=4$ & $6.67 \pm 1.1$ & $15.2 \pm 1.7$ & $87 \pm 18$ & $0.13 \pm 0.03$ & $0.69 \pm 0.16$ & $88.4 \pm 15$ & $7.64 \pm 1.1$ & $3.12 \pm 0.3$ & $0.16 \pm 0.03$ \\
\hline LV 61-5-9 Bivalvia, Akebiconcha soyoae ochotensis, gills, $n=4$ & $57 \pm 17$ & $6.0 \pm 1.1$ & $254 \pm 23$ & $2.5 \pm 0.4$ & $3.92 \pm 0.81$ & $47.1 \pm 13.1$ & $9.96 \pm 1.8$ & $24.7 \pm 6.1$ & $0.31 \pm 0.03$ \\
\hline LV 61-5-9 Bivalvia, Akebiconcha soyoae ochotensis, shell, $\mathrm{n}=4$ & $0.28 \pm 0.04$ & $5.7 \pm 2$ & $43 \pm 9$ & $0.04 \pm 0.01$ & $0.19 \pm 0.02$ & $0.51 \pm 0.04$ & $0.14 \pm 0.03$ & $0.25 \pm 0.04$ & $0.007 \pm 0.002$ \\
\hline LV 61-5-9 Actiniaria, total body, $\mathrm{n}=3$ & $4.64 \pm 1.1$ & $1007 \pm 19$ & $1055 \pm 151$ & $1.2 \pm 0.02$ & $6.74 \pm 1.3$ & $15.4 \pm 2.2$ & $66 \pm 11$ & $3.00 \pm 0.61$ & $0.97 \pm 0.12$ \\
\hline LV 61-5-9 Asteroidea, Freyellidae, fragment, $n=4$ & $2.82 \pm 0.53$ & $465 \pm 61$ & $1140 \pm 72$ & $1.29 \pm 0.03$ & $3.73 \pm 0.62$ & $5.6 \pm 1.0$ & $9.19 \pm 1.2$ & $1.08 \pm 0.07$ & $0.45 \pm 0.11$ \\
\hline LV 61-5-9 Asteroidea, Astropectinidae, fragment, $\mathrm{n}=2$ & $0.76 \pm 0.13$ & $101 \pm 9$ & $418 \pm 23$ & $0.29 \pm 0.03$ & $1.62 \pm 0.21$ & $11.7 \pm 2.0$ & $6.05 \pm 1.2$ & $0.29 \pm 0.06$ & $0.14 \pm 0.03$ \\
\hline LV 61-9-1 Bivalvia, Akebiconcha soyoae ochotensis, soft tissues, $\mathrm{n}=3$ & $23.0 \pm 1.8$ & $17.3 \pm 2.1$ & $230 \pm 41$ & $0.96 \pm 0.21$ & $2.74 \pm 0.62$ & $40.2 \pm 5.8$ & $4.85 \pm 1.61$ & $11.47 \pm 2.1$ & $0.26 \pm 0.03$ \\
\hline LV 61-9-1 Bivalvia, Akebiconcha soyoae ochotensis, gills, $\mathrm{n}=3$ & $80 \pm 11$ & $6.6 \pm 2.1$ & $610 \pm 51$ & $3.76 \pm 1.0$ & $10.85 \pm 1.1$ & $88.6 \pm 15.1$ & $4.86 \pm 1.1$ & $149.8 \pm 13.1$ & $0.06 \pm 0.01$ \\
\hline LV 61-9-1 Bivalvia, Akebiconcha soyoae ochotensis, shell, $\mathrm{n}=3$ & $0.19 \pm 0.02$ & $42 \pm 6$ & $61 \pm 4$ & $0.08 \pm 0.01$ & $0.25 \pm 0.04$ & $0.25 \pm 0.08$ & $0.21 \pm 0.03$ & $0.19 \pm 0.04$ & $0.01 \pm 0.005$ \\
\hline LV 61-9-1 Gastropoda, soft tissues, $\mathrm{n}=4$ & $25.1 \pm 4.1$ & $9 \pm 2.5$ & $826 \pm 59$ & $1.2 \pm 0.1$ & $1.74 \pm 0.21$ & $59.7 \pm 9.8$ & $62 \pm 6$ & $14.48 \pm 2.1$ & $0.24 \pm 0.1$ \\
\hline LV 61-9-1 Gastropoda, shell, $\mathrm{n}=4$ & $0.22 \pm 0.04$ & $21 \pm 3$ & $42 \pm 6$ & $0.06 \pm 0.02$ & $0.28 \pm 0.06$ & $9.5 \pm 1.3$ & $2.83 \pm 0.7$ & $0.13 \pm 0.03$ & $0.009 \pm 0.003$ \\
\hline LV 61-10-1 Bivalvia, Akebiconcha soyoae ochotensis, soft tissues, $n=4$ & $4.16 \pm 1.1$ & $17.5 \pm 3.2$ & $127 \pm 21$ & $0.34 \pm 0.07$ & $0.38 \pm 0.07$ & $18.2 \pm 1.6$ & $4.45 \pm 0.4$ & $7.85 \pm 1.3$ & $0.22 \pm 0.07$ \\
\hline LV 61-10-1 Bivalvia, Akebiconcha soyoae ochotensis, gills, $\mathrm{n}=4$ & $30.3 \pm 11.1$ & $14.6 \pm 0.32$ & $279 \pm 28$ & $1.4 \pm 0.05$ & $1.33 \pm 0.02$ & $19.8 \pm 1.1$ & $3.61 \pm 0.42$ & $28.6 \pm 1.9$ & $0.27 \pm 0.04$ \\
\hline LV 61-10-1 Bivalvia, Akebiconcha soyoae ochotensis, shell, $\mathrm{n}=4$ & $0.3 \pm 0.05$ & $4.0 \pm 0.4$ & $29 \pm 1.9$ & $0.05 \pm 0.01$ & $0.2 \pm 0.03$ & $0.13 \pm 0.03$ & $0.02 \pm 0.01$ & $0.03 \pm 0.01$ & $0.003 \pm 0.001$ \\
\hline LV 61-12-1 Bivalvia, Akebiconcha soyoae ochotensis, shell from the barite zone, $\mathrm{n}=4$ & $0.35 \pm 0.09$ & $2.1 \pm 0.05$ & $40 \pm 9$ & $0.05 \pm 0.01$ & $0.19 \pm 0.03$ & $0.18 \pm 0.07$ & $0.02 \pm 0.008$ & $0.05 \pm 0.01$ & $0.002 \pm 0.001$ \\
\hline LV-61-13-1 Bivalvia, Conchocele bisecta, shell, $\mathrm{n}=2$ & $0.05 \pm 0.01$ & $0.2 \pm 0.04$ & $51 \pm 4$ & $0.04 \pm 0.01$ & $0.2 \pm 0.04$ & $0.08 \pm 0.02$ & $0.06 \pm 0.02$ & $0.12 \pm 0.03$ & $0.005 \pm 0.002$ \\
\hline LV-61-13-1 Polychaeta, Pavelius ushakovi, total body, $\mathrm{n}=3$ & $6.73 \pm 1.1$ & $43.9 \pm 11$ & $3667 \pm 251$ & $1.36 \pm 0.07$ & $5.38 \pm 1.1$ & $17.2 \pm 2.1$ & $98,4 \pm 14.1$ & $16.42 \pm 2.1$ & $4.22 \pm 0.3$ \\
\hline LV-61-13-1 Actiniaria, fragment of foot, $n=2$ & $7.1 \pm 2.1$ & $46.1 \pm 14$ & $176 \pm 13$ & $1.41 \pm 0.2$ & $5.57 \pm 1.5$ & $17.8 \pm 1.3$ & $104 \pm 13$ & $17.52 \pm 1.8$ & $3.99 \pm 0.6$ \\
\hline LV 61-14-1 Actiniaria, fragment of foot, $\mathrm{n}=4$ & $2.26 \pm 0.3$ & $3.7 \pm 1.1$ & $334 \pm 12$ & $0.11 \pm 0.01$ & $0.77 \pm 0.1$ & $2.6 \pm 0.4$ & $13.3 \pm 1.4$ & $0.59 \pm 0.1$ & $0.54 \pm 0.12$ \\
\hline
\end{tabular}

In the dominant symbiotrophic bivalve mollusk Akebiconcha soyoae ochotensis, trace elements were distributed between the soft tissues (body), gills, and carbonate shells as follows. Most of the trace elements $(\mathrm{Cr}, \mathrm{Fe}, \mathrm{Co}, \mathrm{Ni}$, $\mathrm{Cu}, \mathrm{As}, \mathrm{Mo}$, and $\mathrm{Pb}$ ), except $\mathrm{Mn}$, were preferably accumulated in the gills and soft tissues of the bivalve mollusks. It is known that the gills of bivalve mollusks contain the maximum concentrations of most metals in both the shelf filter-feeding mussels (Kristoforova, 1989; Goldberg, 1975) and hydrothermal symbiotrophic mollusks (Demina \& Galkin, 2008, 2016; Kadar et al., 2006; Roesijadi \& Crecelius; 1984; and others). The average Mn concentrations were roughly equal in the soft tissues (including gills) and shells. In contrast to other heavy metals, Mn seems to show geochemical affinity with the carbonate matrix of the shells, as we first discovered in shelf mollusks of the Kara Sea (Demina, Gordeev, Galkin, Kravchishina, \& Aleksankina, 2010), as well as in the deep-sea hydrothermal symbiotrophic mollusks Bathymodiolus sp. (Demina \& Galkin, 2008; Demina et al., 2013). 
The organisms maximally concentrating the trace elements could be subdivided into two groups. The first group comprised polychaete, actinia, and starfish, in which peak concentrations were typical of both the essential trace elements ( $\mathrm{Fe}, \mathrm{Mn}$, and $\mathrm{Ni}$ ) and the toxic ones ( $\mathrm{Pb}$ and $\mathrm{As}$ ) (Table 2). Note that the highest Fe concentrations (3667 $\mu \mathrm{g} / \mathrm{g} \mathrm{DW}$ ) were found in the polychaete Pavelius ushakovi, which inhabits exclusively active seep zones, and which is taxonomically close to hydrothermal polychaete Alvinella, whose tissues also contained anomalously high concentrations of many trace elements (Demina \& Galkin, 2010). In terms of the feeding type, Pavelius ushakovi is similar to polychaetes of genus Paralvinella, which abound in the vicinities of hydrothermal vents of the Juan de Fuca Ridge and Guaymas Basin (Galkin, 2002). Sea anemones dwelling in the Deryugin Basin at the depths greater than $1400 \mathrm{~m}$ are omnivorous predators and feed not only on the smaller organisms, but can also consume organic detritus and the particles of bacterial mats. Starfishes (Asteroidea) are mostly predators by their feeding type, whereas the starfishes of the family Freyellidae feed on plankton. The planktonic and microbial biomass is known to be characterized by a high adsorption capacity with respect to heavy metals, because these organisms are micrometer- and nanometer-sized.

The other group includes the symbiotrophic Vesicomyidae Akebiconcha soyoae ochotensis and Conchocele bisecta, whose gills (which host endosymbiont bacteria) contained high concentrations of many elements and peak concentrations of such essential elements as $\mathrm{Cr}, \mathrm{Co}$, and $\mathrm{Cu}$ (Table 2). Elevated concentrations of many heavy trace elements were found in the gills of Conchoele bisecta (Kuznetsov, Lukashin, \& Shmelev, 1989), and in the gills and mantle of the Vesicomyidae Calyptogena diagonalis from a methane seep field at the Costa Rica coast (Vargas et al., in press). Concentrations of the trace elements in these Vesicomyidae are close to those in symbiotrophic mollusks at high-temperature deep-sea hydrothermal fields in the Mid-Atlantic Ridge and East Pacific Rise (Demina \& Galkin, 2008, 2010; Kadar et al., 2005; Roesijadi \& Crecelius, 1984).

Obviously, to determine the character of trace metal bioaccumulation in organisms from different biotopes, we should to compare the metal concentrations in the same genera. To do this, it is useful to compare organisms affiliating with the same class Bivalvia, which was dominant in both hydrothermal vents and seeps biotopes.

An important quantitative parameter of the concentration function of a biota is the bioconcentration factor $(\mathrm{BCF})$, which is defined as the ratio of the concentration of a metal in a given organism to concentration of this metal in water of the biotope: $\mathrm{BCF}=\mathrm{C}_{\text {met.org. }} / \mathrm{C}_{\text {met.wat. }}$ Based on data from Tables 1 and 2, we have calculated BCF of the trace elements. These values for most of the elements are greater than $n \cdot 10^{3}$. This highlights the ability of bivalve mollusks to concentrate the trace elements. Regard must be paid to the maximal BCF (from $\mathrm{n} \cdot 10^{3}$ to $\left.\mathrm{n} \cdot 10^{5}\right)$ was detected for both essential $(\mathrm{Fe}, \mathrm{Cu}, \mathrm{Ni}$, and $\mathrm{Cr}$ ) and toxic $(\mathrm{Cd}, \mathrm{Hg}$, and $\mathrm{Pb})$ heavy metals. This confirms our earlier conclusion that trace elements are biologically accumulated with no selectivity (i.e., regardless of their biochemical importance) by bivalve mollusks inhabiting different biotopes.

To evaluate the partition of trace elements between the soft tissues and carbonate shells, we apply the coefficient $K=\mathrm{TE}_{\text {soft.tis }} / \mathrm{TE}_{\text {shell }}$ i.e., the ratio of a trace element concentration in soft tissues to concentration of this element in shell (Table 3).

Table 3. Average concentrations ( $\mu \mathrm{g} / \mathrm{g}$ d.w.) of heavy metals in the soft tissues (numerators) and shells (denominators) of bivalve mollusks from the Deryugin Basin in the Sea of Okhotsk, and the Rainbow deep-sea high temperature hydrothermal vent field at the Mid-Atlantic Ridge

\begin{tabular}{ccc}
\hline Element & $\begin{array}{c}\text { Deryugin Basin, } \\
\text { Sea of Okhotsk } \\
(n=35)\end{array}$ & $\begin{array}{c}\text { Rainbow hydrothermal vent field, MAR* } \\
(n=36)\end{array}$ \\
\hline $\mathrm{Cr}$ & $39.8 / 0.3$ & $2.46 / 1.0$ \\
$\mathrm{Mn}$ & $11.5 / 11$ & $27.1 / 92.3$ \\
$\mathrm{Fe}$ & $276 / 43$ & $1688 / 673$ \\
$\mathrm{Co}$ & $1.4 / 0.05$ & $4.65 / 2.69$ \\
$\mathrm{Ni}$ & $3.4 / 0.2$ & $39 / 41$ \\
$\mathrm{Cu}$ & $64.9 / 0.36$ & $97.6 / 1.6$ \\
$\mathrm{As}$ & $6.9 / 0.10$ & $15.8 / 2.9$ \\
$\mathrm{Cd}$ & n.a. & $0.92 / 0.24$ \\
$\mathrm{~Pb}$ & $0.22 / 0.07$ & $9.5 / 2.7$ \\
$\mathrm{Hg}$ & n.a. & $0.19 / 0.03$ \\
\hline
\end{tabular}

* (Demina, Galkin, 2008); n.a. means not analyzed. 
The coefficient $K$ characterizes accumulation of a given trace element in the soft tissues of the bivalve mollusks during their metabolism relative to the concentration of this element in the shells, which are in a direct contact with the biotope water. It is known that trace elements are accumulated in mollusk shells by means of incorporation of the elements into the biomineral structure during metabolism and due to a passive physicochemical adsorption of these elements on the carbonate matrix (Phillips, 1990; Rainbow, 1995).

In the symbiotrophic bivalve mollusks Akebiconcha soyoae ochotensis and Conchocele bisecta found at methane seeps in the Sea of Okhotsk, the coefficient $K \geq 1$ for all of the elements and varies within the range of 1.05 for $\mathrm{Mn}$ to $180 \mathrm{for} \mathrm{Cu}$ (Figure 3). This indicates that the elements are preferably accumulated in the soft tissues. It is worth mentioning $\mathrm{Cu}$, whose $K$ is the highest and which is known to form a rather stable compounds with organic chelates. Compared to other trace elements, $\mathrm{Mn}$ is prone to be more strongly enriched in the carbonate material of the shells, whose average Mn concentration is close to that in the soft tissues. The elements considered herein can be arranged in the following sequence according to an increase in their $K$ values: $\mathrm{Mn}<\mathrm{Fe}$ $<\mathrm{Ni}<\mathrm{Co}<\mathrm{Pb}<\mathrm{As}<\mathrm{Cr}<\mathrm{Cu}$.

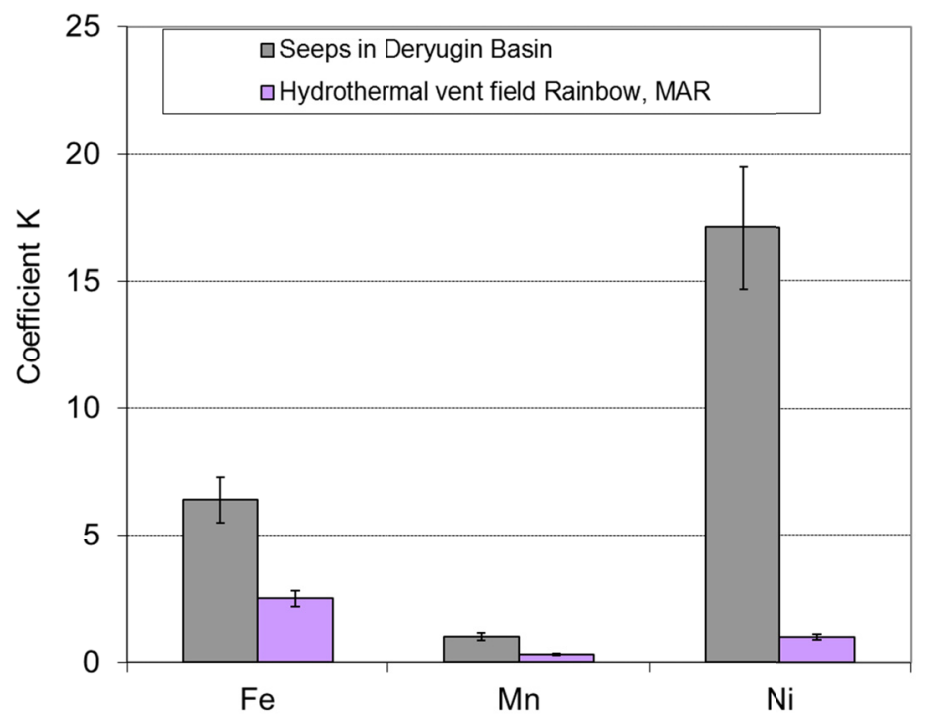

Figure 3. Comparison of the coefficient $K=\mathrm{TE}_{\text {soft.tis }} / \mathrm{TE}_{\text {shell }}$ - the ratio of the average concentrations of trace elements in the soft tissues and the average concentrations in the shells of bivalve mollusks from the area of methane seeps in the Deryugin Basin, and the Rainbow high-temperature hydrothermal vent field at the Mid-Atlantic Ridge

In reduced biotopes with high $\mathrm{CH}_{4}$ and $\mathrm{H}_{2} \mathrm{~S}$ concentrations, chemosynthesizing microbial communities catalyze anaerobic oxidation of methane and thereby utilize coenzymes, which contain trace elements concentrated in the live matter (Glass \& Orphan 2012; Glass et al., 2014). The trophic strategy of the symbiotrophic mollusks related to bacterial chemosynthesis may be a reason for the accumulation of higher concentrations of trace elements in the soft tissues, first of all, in gills of the symbiotrophic mollusks, which are dominant in the areas of methane seeps in the Deryugin Basin. This is obviously reflected in the high values of the coefficient $K$. Moreover, as it was mentioned above, the benthic fauna functions there under conditions of low content of suspended matter in water and bioavailable metal forms (except Mn), which are more favorable for bioaccumulation of elements mostly in soft tissues, than conditions of biotopes at the Rainbow hydrothermal field. At the same time, reduced sulfur compounds, which are synthesized via microbial sulfate reduction, form soluble and insoluble complexes in the water of the Deryugin Basin. These complexes bind certain metals when precipitated and thus reduce the biological availability of these metals (Edgcomb et al., 2004).

The values of $K$ of all of the trace elements in symbiotrophic mollusks from the Deryugin Basin are notably higher than in analogous taxa from another reduced biotope: the Rainbow hydrothermal field at MAR (Figure 3). This means that symbiotrophic mussels at the Rainbow hydrothermal field concentrate trace elements more effectively in their shells than in the soft tissues. The possible interpretation could be as follows. First, the concentration levels and bioavailability of the trace elements in the biotopes' waters is an important abiotic parameter for the bioaccumulation of trace elements in the mollusks' shells as their external organ is. As it was 
mentioned above, the dominant occurrence form of $\mathrm{Fe}, \mathrm{Mn}, \mathrm{Ni}, \mathrm{Cd}$, and $\mathrm{Pb}$ in the biotope water of the Rainbow hydrothermal field is a particulate one (Kadar et al., 2005), while the bioavailable trace metal dissolved species are of subordinate importance. Second, the high turbidity of water at the Rainbow hydrothermal vent field can obviously suppress the filtration activity of the mollusks (Desbruyéres, Almeida, \& Biscoito, 2000) and, hence, the bioaccumulation of the trace elements in their soft tissues.

\section{Conclusions}

We have examined the principal bioaccumulation characteristics of heavy metals $(\mathrm{Fe}, \mathrm{Mn}, \mathrm{Cu}, \mathrm{Co}, \mathrm{Cd}, \mathrm{Ni}, \mathrm{Cr}$, and $\mathrm{Pb}$ ) and the metalloid As in the dominant taxa of macrobenthic communities at methane seeps in the Sea of Okhotsk. Most of these organisms (symbiotrophic mollusks, whose gills are inhabited by endosymbiont bacteria, and polychaetes) are known to be trophically dependent on autochthonous organic matter, which is produced by chemoautotrophic bacteria in the course of chemosynthesis and methanotrophy (Jannasch \& Wirsen, 1979; Roesijadi \& Crecelius, 1984). The bioconcentration factor (BCF) in the soft tissues of the bivalve mollusks is, according to our data, greater than $\mathrm{n} \cdot 10^{3}$ for most trace elements, and this suggests that the bivalve mollusks are able to concentrate much trace elements. It is worth mentioning that the highest $\mathrm{BCF}$ values (from $\mathrm{n} \cdot 10^{3}$ to $\left.\mathrm{n} \cdot 10^{5}\right)$ were determined for both essential $(\mathrm{Fe}, \mathrm{Mn}, \mathrm{Cu}, \mathrm{Co}, \mathrm{Ni}$, and $\mathrm{Cr}$ ) and toxic $(\mathrm{Cd}, \mathrm{Hg}$, and $\mathrm{Pb}$ ) metals, as well as for the metalloid As. This likely confirms the conclusion that bioaccumulation of trace elements is a nonselective process.

To elucidate the specifics of bioaccumulation of heavy metals by bivalve mollusks in the reducing biotopes, we suggest to use the coefficient $\mathrm{K}$, which characterizes accumulation of trace elements in soft tissues in the course of metabolism relative to accumulation of these elements in shells, which occur in physical contact with the water of the biotope. Symbiotic mollusks in the Deryugin Basin are characterized by $\mathrm{K}>1$ for all of the elements. In mollusks from the Deryugin Basin, the highest $\mathrm{K}$ value was determined for $\mathrm{Cu}$ (180), which confirms that $\mathrm{Cu}$ is prone to form organic complexes, while the lowest value of 1.05 was determined for $\mathrm{Mn}$, which is more than the other elements prone to be accumulated in the carbonate shells.

As it is known, trophic strategy as one of the biotic factors that control bioaccumulation and manifests itself when concentrations of the trace elements are compared in tissues of mollusks from the oxidized and reduced biotopes. Symbiotrophic feeding type of mollusks inhabiting areas with methane seeps may be a reason for the relatively significant accumulation of the trace elements in soft tissues, first of all, gills, of the symbiotrophic mollusks, as is clearly reflected in the high $\mathrm{K}$ values. At the same time, the coefficient $\mathrm{K}$ of all of the trace elements is notably higher for symbiotic mollusks in the Deryugin Basin than for analogous taxa in another reducing biotope: the Rainbow hydrothermal vent field at MAR. Given that the character of trophic strategy is the similar, this difference in the $\mathrm{K}$ values may suggests an importance of such abiotic factor as water turbidity: the high turbidity of water at the Rainbow vent field likely suppresses the normal metabolism of the mollusks and thus diminishes the bioaccumulation of the trace elements as compared to organisms in the biotope with clearer water in the Deryugin Basin.

\section{Acknowledgments}

The authors are grateful to the team of the expeditions aboard the $\mathrm{R} / \mathrm{V}$ Akademik M.A. Lavrentyev and the crew of this vessel for the help in collecting the materials for our research. This research was performed in the framework of the state assignment of Russia (theme no. 0149-2018-0008), and was partially financially supported by Russian Science Foundation (grant 14-50-00095) for collecting and generalizing materials.

\section{References}

Bennett, S. A., Statham, P. J., Green, D. R. H., Le Bris, N. J., McDermott, M., Prado, F., ... German, C. R. (2011). Dissolved and particulate organic carbon in hydrothermal plumes from the East Pacific Rise, 9 degrees 50' N. Deep-Sea Res. Part I., 58(9), 922-931. https://doi.org/10.1016/j.dsr.2011.06.010

Conway, T. M., \& John, S. G. (2014). Quantification of dissolved iron sources to the North Atlantic Ocean. Nature, 511(7508), 212-215. https://doi.org/10.1038/nature13482

Corliss J. B., \& Ballard, R. D. (1977).Oases of life in the cold abyss. National Geographic, 152, 440-453

Demina L. L., \& Atnashev, V. B. (1989). Anomalous behavior of metals in zone of submarine gas seep of Paramushir Island, Sea of Okhotsk. Oceanology, 29(6), 952- 959

Demina L. L. \& Galkin, S. V. (2008). On the role of abiogenic factors in the bioaccumulation of heavy metals by the hydrothermal fauna of the Mid-Atlantic Ridge. Oceanology, 48(6), 784-797. 
Demina L. L. \& Galkin, S. V. (2010). Polychaete Alvinella pompejana-superthermophile and "a champion in metals. Priroda, 8, 14-21. [in Russian].

Demina L. L. \& Galkin, S. V. (2016). Factors controlling the trace metal distribution in hydrothermal vent organism. In L. L. Demina and S. V. Galkin (Eds.), Trace metal Biogeochemistry and Ecology of Deep-Sea Hydrothermal Vent Systems (pp. 97-122). Springer.

Demina, L. L., Gordeev, V. V., Galkin, S. V., Kravchishina, M. D., \& Aleksankina, S. P. (2010). The biogeochemistry of some heavy metals and metalloids in the Ob River estuary-Kara Sea section. Oceanology, 50(5), 729-742.

Demina, L. L., Holm, N. G., Galkin, S. V., \& Lein, A. Yu. (2013). Some features of the trace metal biogeochemistry in the deep-sea hydrothermal vent fields (Menez Gwen, Rainbow, Broken Spur at the MAR and $9^{\circ} 50^{\prime} \mathrm{N}$ at the EPR): a synthesis. J. Mar. Syst., 126, 94-105.

Desbruyéres, D., Almeida, A., Biscoito, M. (2000). A review of the distribution of hydrothermal vent communities along the northern Mid-Atlantic Ridge: dispersal vs. environmental controls. Hydrobiologia, 440, 201-216.

Edgcomb, V. P., Molyneaux, S. J., Saito, M. A., Lloyd, K., Böer, S., \& Wirsen, C. O. (2004). Sulfide ameliorates metal toxicity for deep-sea hydrothermal vent archaea. App. Environ. Microbiol. 70, 25512555.

Edmond, J. M., Von Damm, K. L. \& McDuff, R. E. (1982). Chemistry of hot springs on the East Pacific Rise and their affluent dispersal. Nature, 297, 187-191.

Gal'chenko, V. F. (1989). Methane oxidation in the has hydrate reservoirs in the Sea of Okhotsk. In Proceedings of 9th International Symposium on Environmental Biogeochemistry (P.85). Moscow, Russia. [in Russian].

Galkin, S. V. (1993). Benthic community based on chemosynthetic derived sources in the area of Paramushir gas-hydrate seepage (Sea of Okhotsk). In: First Workshop on Russian-German Cooperation in the Sea of Okhotsk - Kuril Island Arc System. Moscow.

Galkin, S. V. (2002). Hydrothermal Communities of the World Ocean. Structure, Typology, and Geography. Moscow: GEOS. [in Russian].

German C. R. \& Von Damm, K. L. (2004). Hydrothermal processes. In H. D. Holland and K. K. Turekian (Eds.), Treatise on Geochemistry, 6 (pp. 181-222).

German, C. R., Legendre, L. L., Sander, S. G., Niquil, N., Luther Iii, G. W., Bharati, L., Han, X., \& Le Bris, N. (2015). Hydrothermal Fe cycling and deep ocean organic carbon scavenging: Model-based evidence for significant POC supply to seafloor sediments. Earth Planet. Sci. Let., 419(1), 143-153. http://dx.doi.org/ 10.1016/j.epsl.2015.03.012

Glass J. B., \& Orphan, V. J. (2012). Trace metal requirements for microbial enzymes involved in the production and consumption of methane and nitrous oxide. Front. Microbio., 3(61). https://doi.org/10.3389/fmicb. 2012.00061

Glass, J. B. Yu, H., Steele, J. A., Dawson, K. S., Sun, S., Chourey, K., Pan, C., Hettich, R. L., \& Orphan, V. J. (2014). Geochemical, metagenomic and metaproteomic insights into trace metal utilization by methane-oxidizing microbial consortia in sulphidic marine sediments. Environ. Microbiol., 16(6), 15921611.

Goldberg, E. D. (1975). The mussel watch—a first step in global marine monitoring. Mar. Pollut. Bull., 6, 111120.

Greinert, J. Bollwerk, S., Derkachev, A., Bohrmann, G., \& Suess, E. (2002). Massive barite deposits and carbonate mineralization in the Derugin Basin, Sea of Okhotsk: precipitation processes at cold seep sites. Earth Planet. Sci. Lett., 203, 165-180.

Jannasch, H. W, Wirsen, G. O. (1979). Chemosynthetic Primary Production at East Pacific Sea Floor Spreading Centers. Bioscience, 79, 592-598.

Kádár, E., Costa, V., Martins, I., Santos, R. S., \& Powell, J. J. (2005). Enrichment in trace metals (Al, Mn, Co, $\mathrm{Cu}, \mathrm{Mo}, \mathrm{Cd}, \mathrm{Fe}, \mathrm{Zn}, \mathrm{Pb}$ and $\mathrm{Hg}$ ) of the macro-invertebrate habitats at hydrothermal vents along the Mid-Atlantic Ridge. Hydrobiol., 548, 191-205. 
Kádár, E., Costa, V., \& Santos, R. S. (2006). Tissue partitioning of micro-essential metals in the vent bivalve Bathymodiolus azoricus and associated organisms (endosymbiont bacteria and a parasite polychaete) from geochemically distinct vents of the Mid-Atlantic Ridge. J. Sea Res., 56, 45-52.

Kádár, E., Costa, V., \& Segonzac, M. (2007). Trophic influences of metal accumulation in natural pollution laboratories at deep-sea hydrothermal vents at the Mid-Atlantic Ridge. Sci. Tot. Environ., 373, 464-472.

Kristoforova, N. K. (1989). Bioindication and Monitoring of Seawater Pollution by Heavy Metals., Leningrad: Nauka. 192p. [in Russian].

Koschinski, A. (2016). Sources and forms of trace metals taken up by hydrothermal vent mussels, possible adaptation and mediation strategies. In L. L. Demina and S. V. Galkin (Eds.),Trace metal Biogeochemistry and Ecology of Deep-Sea Hydrothermal Vent Systems (pp. 97-122). Springer.

Kudinova-Pasternak, R. K. (1951).On the interaction of biological filters with water masses. Vopr. Geogr., 1, 26-34. [in Russian].

Kusnetsov, A. P.,.Levenstein, R. Ja. (1988). Pavelius uschakovi gen. et sp. n. (Polychaeta, Am-pharetidae) from the area of Paramushir gas-hydrate seepage of the Sea of Okhotsk. Zoologicheskii zhurnal, 67(6), 819-825.

Kuznetsov, A. P., Lukashin, V. N., \& Shmelev, I. P. (1989). Content of transition metals in bottom animals of the Paramushir gas hydrate seep." Oceanology, 29(5), 767- 773. [in Russian].

Kuznetsov, A. P., Rass, T. S., \& Galkin, S.V. (1989). Bottom community of Paramushir gas-hydrate seepage”. Zoologicheskii Zhurnal, 68(1), 5-14 [in Russian].

Nishioka, J., Obata, H., \& Tsumune, D. (2013). Evidence of an extensive spread of hydrothermal dissolved iron in the Indian Ocean. Earth Planet. Sci. Lett., 361, 26-33.

Operation Report of Sakhalin Slope Gas Hydrate Project. (2011). R/V Akademik M. A. Lavrentyev Cruise 56. Shoji, H., Jin, Y. K., Obzhirov, A. I., \& Baranov, B. V. (Eds.). Vladivostok. 335 p.

Paull, C. K., Jull, A. J. T., Toolin, L. J., \& Linick, T. (1985). Stable isotope evidence for chemosynthesis in abyssal seep community. Nature, 317, 709-711.

Phillips D. J. H. (1990). Use of macroalgae and invertebrates as monitors of metal levels in estuaries and coastal waters. In Furness R. W, Rainbow P. S. (Eds.) Heavy metals in the Marine Environment (pp. 81-100). Boca Raton: CRC Press.

Rainbow P. S. (1995). Biomonitoring of heavy metal availability in the marine environment. Mar. Pollut. Bull., 31(4-12), 183-192.

Roesijadi, G. \& Crecelius, E. A. (1984). Elemental composition of the hydrothermal vent clam Calyptogena magnifica from the East Pacific Rise. Mar. Biol., 83(2), 155-161.

Vargas, J. A., Hilton, D. R., Ramírez, C., \& Molina, J. (in press). Metals in bivalves from the Jaco Scar seep, Pacific coast of Costa Rica. J. Tropic. Biol.

Wang W-X. (2002). Interactions of trace metals and different marine food chains. mar. Ecol. Progr. Ser., 243, 295-309.

\section{Copyrights}

Copyright for this article is retained by the author(s), with first publication rights granted to the journal.

This is an open-access article distributed under the terms and conditions of the Creative Commons Attribution license (http://creativecommons.org/licenses/by/4.0/). 